\title{
Analisis Keputusan Pembelian Konsumen dari Sisi Normatif dan Informatif Pada Hypermart Cibubur Junction, Jakarta Timur
}

\author{
Ade Onny Siagian ${ }^{1}$, Trisna Fajar Prasetyo ${ }^{2 *}$ \\ ${ }^{1,2}$ Program Studi Manajemen dan Bisnis, Fakultas Ekonomi, Universitas Bina Sarana \\ Informatika, Jakarta, Indonesia \\ Email: ${ }^{1}$ ade.aoy@bsi.ac.id, ${ }^{2 *}$ trisna.tfp@bsi.ac.id
}

\begin{abstract}
The purpose of this study was to analyze the factors that influence community purchasing decisions in terms of normative and informative marketing that is always changing and developing in the Giant Pamulang supermarket, South Tangerang. This study uses descriptive qualitative method using observation, interviews and questionnaires. The sample in this study is a buyer subscription at Hypermart Cibubur supermarket, East Jakarta. The form of analysis focuses on normative and informative factors and a combination of both in the process of purchasing decisions in supermarkets related to products in the form of consumer goods. From the observations, the decision to buy the community and consumers of supermarkets Hypermart Cibubur, East Jakarta, is influenced by several factors, including: consumers are more concerned about product quality and start paying attention to the moral and social responsibility of the company, lifestyle changes due to an increase in the amount of income received, education the better, and also because of changes in cultural values and the location of supermarkets that are not far from the residence and physical facilities of supermarkets.
\end{abstract}

Keywords: Normative and Informative Marketing Factors, Purchasing Decisions.

\begin{abstract}
Abstrak
Tujuan penelitian ini adalah untuk menganalisa faktor - faktor yang mempengaruhi keputusan pembelian masyarakat dari segi normatif dan informatif pemasaran yang selalu berubah dan berkembang pada Hypermart Cibubur Junction, Jakarta Timur. Penelitian ini menggunakan metode deskriptif kualitatif dengan menggunakan cara pengamatan, wawancara dan kuisioner. Sampel dalam penelitian ini adalah langganan pembeli di Jakarta Timur. Bentuk analisisnya fokus pada faktor normatif dan informatif serta gabungan keduanya dalam proses keputusan pembelian di supermarket terkait produk- produk berupa barang-barang konsumsi. Dari hasil pengamatan Keputusan pembelian masyarakat dan konsumen supermarket Hypermart Cibubur, Jakarta Timur, dipengaruhi oleh beberapa faktor antara lain: konsumen lebih konsen terhadap kualitas produk dan mulai memperhatikan sisi moral dan tanggung jawab sosial perusahaan, perubahan gaya hidup karena peningkatan jumlah pendapatan yang diterima, pendidikan yang semakin baik, dan juga karena perubahan nilai-nilai budaya serta lokasi supermarket yang tidak jauh dari tempat tinggal dan fasilitas fisik supermarket
\end{abstract}

Kata Kunci: Faktor Normatif dan Informatif Pemasaran, Keputusan Pembelian. 


\section{PENDAHULUAN}

Pertumbuhan ekonomi yang tumbuh pesat di Indonesia, akan menyebabkan perubahan di berbagai sektor termasuk di sektor industri dan produksi dan dalam kegiatan ritel di Indonesia yang telah berkembang menjadi bisnis berskala besar. Pesatnya perkembangan bisnis ritel (dalam bentuk supermarket) tidak dapat dipisahkan dari faktor peningkatan jumlah penduduk Indonesia dan juga peningkatan jumlah pendapatan per kapita penduduk Indonesia yang menyebabkan standar hidup masyarakat Indonesia meningkat. Ini berdampak pada pola perilaku belanja pelanggan. Di mana semakin tinggi pendidikan dan meningkatnya standar hidup seseorang, permintaan tempat belanja yang nyaman dan dapat menyediakan segala macam kebutuhan konsumen di satu lokasi semakin dibutuhkan. Meskipun ada perubahan, pemasaran tidak dapat lolos dari tiga komponen yang selalu menyertainya; konsumen, pesaing, dan perusahaan. Ketiga komponen ini selalu hadir di setiap diskusi tentang pemasaran. Terutama jika pemasaran bersifat operasional, dinamikanya tidak terpisah dalam konteks pertumbuhan ekonomi. Karena bagaimanapun pertumbuhan ekonomi menimbulkan pemasukan dan kemakmuran, dari uraian tersebut dapat dirumuskan Bagaimana proses pengambilan keputusan pembelian masyarakat pada Hypermart Cibubur Junction, Jakarta Timur dan apa saja faktor - faktor yang mempengaruhi keputusan pembelian masyarakat pada Hypermart Cibubur Junction, Jakarta Timur.

\section{KAJIAN TEORI}

Menurut (P. Kotler, 1991);(dan Keller, 2013), Konsep pemasaran menyatakan bawa kunci untuk mencapai tujuan organisasi yang ditetapkan adalah perusahaan tersebut harus menjadi lebih efektif dibandingkan para pesaing dalam menciptakan, menyerahkan, dan mengkomunikasikan nilai pelanggan kepada pasar sasaran yang terpilih. Dalam tataran literatur akademik pada dunia pemasaran dikenal istilah Bauran Pemasaran yang biasa dikenal sebutan - 4P (Product, Price, Place dan Promotion). Secara aplikasi faktual 4P ini harus dibuat menarik secara kontekstual. Seperti halnya dengan produk, tidak hanya harus menimbulkan daya tarik pembeli karena mutu atau kualitas, melainkan juga menarik karena dapat memenuhi kebutuhan dan memuaskan keinginan. Kemudian terkait dengan harga (Price), tentu dituntut memperhatikan kepatutan dan prinsip keterjangkauan. Selanjutnya menyangkut penempatan produk (Place), tentu bukan saja berkaitan dengan armada distribusi melainkan juga memperhatikan pola "saluran" pemasaran kredibel dan tempat yang strategis. Sementara itu, ternyata bentuk komunikasi bisnis dalam konteks promosi (Promotion) baik itu dalam bentuk penjualan pribadi, periklanan, promosi penjualan, publisitas, pemasaran langsung dan pemasaran secara on-line - nuansa dunia internet tidak kalah pentingnya untuk dibuat menarik(Onny Siagian, 2020).

\section{Perilaku Konsumen}

Perilaku konsumen adalah tindakan-tindakan yang dilakukan individu, kelompok atau organisasi yang berhubungan dengan proses pengambilan keputusan dalam mendapatkan, menggunakan barang-barang atau jasa ekonomis yang dapat dipengaruhi oleh lingkungan (Khafidin, 2020). Menurut American Marketing Association, perilaku konsumen adalah interaksi dinamis antar pengaruh kognisi, perilaku dan kejadian di sekitar kita dimana manusia melakukan aspek pertukaran dalam kehidupan mereka (A. Firmansyah, 2019).

Perilaku konsumen mempelajari bagaimana individu, kelompok dan organisasi memilih, membeli, memakai serta memanfaatkan barang, jasa, gagasan, atau pengalaman dalam rangka memuaskan kebutuhan dan keinginan konsumen. Perilaku konsumen akan menentukkan proses pengambilan keputusan dalam pembelian mereka, 
proses tersebut merupakan sebuah pendekatan penyesuaian masalah yang terdiri dari lima tahap yang dilakukan konsumen, kelima tahap tersebut adalah pengenalan masalah, pencarian informasi, penilaian alternatif, membuat keputusan, dan perilaku pasca pembelian (Hanum \& Hidayat, 2017). Perilaku konsumen secara umum dipengaruhi oleh faktor-faktor utama kebudayaan, sosial, pribadi, dan psikologis (P. Kotler, 2017).

\section{Keputusan Pembelian}

Pengambilan keputusan pembelian pada dasarnya merupakan proses pemecahan masalah. Schiffman dan Kanuk (2004) mendefinisikan keputusan pembelian sebagai pemilihan suatu tindakan dari dua atau lebih pilihan alternatif. Lebih lanjut, menurut (P. Kotler \& Armstrong, 2018) menyatakan bahwa keputusan pembelian sebagai preferensi yang dibentuk oleh pelanggan atas merek- merek yang ada di dalam kumpulan pilihan. (M. Kotler \& Kotler, 2004) menunjukkan bahwa keputusan konsumen berorientasi pada target dan konsumen perlu untuk membuat pilihan mengenai keputusan yang berbeda selama proses pemecahan masalah. (A. B. P. Kotler, 2014) menyatakan bahwa keputusan pembelian adalah proses belajar dari keputusan untuk benar-benar membeli produk. Sedangkan (M. A. Firmansyah, 2019) mengarahkan bahwa inti dari proses keputusan konsumen adalah proses interaksi yang menggabungkan pengetahuan untuk meningkatkan kinerja, dan memilih satu sama lain.

Indikator normatif, yaitu representasi kelompok terhadap seseorang melalui norma sosial yang harus dipatuhi dan diikuti. Pengaruh normatif jika ada yang kuat. Untuk menemukan norma yang ada, penerimaan sosial, dan layanan yang dapat digunakan sebagai simbol norma social. Informasi Informasi, kelompok referensi akan menjadi pilihan produk dari konsumen, karena kelompok sangat penting karena bahanbahannya, karena mereka memiliki pengetahuan dan informasi yang lebih baik.(Siagian et al., 2020)

\section{METODE PENELITIAN}

Populasi dalam penelitian ini di gunakan beberapa konsumen yang di pilih sebagai sampel. Jumlah sampel yang digunakan sebanyak 100 orang yang mewakili sebagian konsumen Hypermart Cibubur Junction, Jakarta Timur. Data diperoleh dengan dua metode yaitu metode kuesioner dan wawancara.

Data didapat dengan metode kuesioner dilakukan dengan menyebarkan beberapa kuesioner yang di bagikan kepada responden. Data ditambah dengan mengajukan pertanyaan kepada responden (konsumen) yang kemudian dalam hal metode wawancara di lakukan dengan mengadakan tanya jawab secara langsung dengan para individu (pengunjung) supermarket. Langkah selanjutnya menghimpun data yang kemudian dianalisa secara kualitatif Deskriptif

\section{HASIL PENELITIAN DAN PEMBAHASAN}

Pengelompokkan Berdasar Jenis Kelamin

\begin{tabular}{|l|c|c|}
\hline \multicolumn{1}{|c|}{ Jenis Kelamin } & Banyaknya Responden & persentase \\
\hline Pria & 35 & 0,35 \\
wanita & 65 & 0,65 \\
\hline Jumlah & 100 & 100,00 \\
\hline
\end{tabular}

Sumber: Data diolah, 2021 
Pengelompokkan Berdasar Umur Konsumen

\begin{tabular}{|l|c|c|}
\hline \multicolumn{1}{|c|}{ Usia Konsumen } & Banyaknya Responden & Persentase \\
\hline 15-24 tahun & 20 & 0,20 \\
24-44 tahun & 55 & 0,55 \\
44 tahun ke atas & 25 & 0,25 \\
\hline \multicolumn{1}{|c|}{ Jumlah } & 64 & 100,00 \\
\hline
\end{tabular}

Sumber: Data diolah 2021

Pengelompokkan Berdasar Tingkat Pendidikan

\begin{tabular}{|c|c|c|}
\hline $\begin{array}{c}\text { Tingkat } \\
\text { Pendidikan }\end{array}$ & Banyaknya Responden & Persentase \\
\hline SMA & 35 & 0,35 \\
Perguruan tinggi & 65 & 0,65 \\
\hline Jumlah & 64 & 100,00 \\
\hline
\end{tabular}

Sumber : Data Diolah. 2021

Pengelompokkan Berdasar Jenis Pekerjaan

\begin{tabular}{|l|c|c|}
\hline \multicolumn{1}{|c|}{ Jenis Pekerjaan } & $\begin{array}{c}\text { Banyaknya } \\
\text { Responden }\end{array}$ & persentase \\
\hline Pegawai & 30 & 0,30 \\
Negeri/Swasta & 50 & 0,50 \\
Usahawan/Wiraswasta & 20 & 0,20 \\
Tidak/Belum Bekerja & & 100 \\
\hline \multicolumn{1}{|c|}{ jumlah } & 100 & \\
\hline
\end{tabular}

Sumber: Data diolah 2021

Pengelompokkan Berdasarkan Frekuensi Pembelian

\begin{tabular}{|l|c|c|}
\hline \multicolumn{1}{|c|}{$\begin{array}{c}\text { Frekuensi Pembelian } \\
\text { Per Bulan }\end{array}$} & $\begin{array}{c}\text { Banyaknya } \\
\text { Responden }\end{array}$ & Persentase \\
\hline Satu Kali & 0 & 0,00 \\
$\begin{array}{l}\text { Dua Sampai Empat } \\
\text { kali }\end{array}$ & 60 & 0,60 \\
Lebih Dari Empat kali & 40 & 0,40 \\
\hline \multicolumn{1}{|c|}{ Jumlah } & 100 & 100,0 \\
\hline
\end{tabular}

Sumber: Data diolah 2021 
Pengelompokkan Berdasar Status Perkawinan

\begin{tabular}{|l|c|c|}
\hline Status Perkawinan & Banyaknya Responden & Persentase \\
\hline Tidak/Belum & 12 & 0,12 \\
Kawin & 28 & 0,28 \\
Kawin Tanpa Anak & 45 & 0,45 \\
Kawin dengan & & \\
anak dua atau & 15 & 0,15 \\
lebih & & \\
Kawin dengan & & \\
\hline
\end{tabular}

Sumber: Data diolah 2021

Pengelompokkan berdasarkan Hypermart Cibuburrkan tingkat pengahasilan

\begin{tabular}{|c|c|c|}
\hline Status Perkawinan & Banyaknya Responden & Persentase \\
\hline$>4$ juta per bulan & 70 & 0,70 \\
$>2$ juta per bulan & 18 & 0,18 \\
$<2$ juta per bulan & 12 & 0,12 \\
\hline Jumlah & 100 & 100,0 \\
\hline
\end{tabular}

Sumber: Data diolah 2021

Pengelompokkan berdasarkan frekuensi kunjungan

\begin{tabular}{|l|c|c|}
\hline Status Perkawinan & Banyaknya Responden & Persentase \\
\hline Lebih dari 3 x & 25 & 0,25 \\
sebulan & 45 & 0,45 \\
Lebih dari 2 x & 30 & 0,30 \\
sebulan & & \\
Satu kali sebulan & 100 & 100,0 \\
\hline \multicolumn{1}{|c|}{ Jumlah } & & \\
\hline
\end{tabular}

Sumber: Data diolah 2021

Berdasarkan kuiisioner maka dapat di analisis perilaku para konsumen dalam pengambilan keputusan pembelian sebagai berikut:

Rata-rata pengunjung supermarket adalah kaum wanita sebanyak 65 persen; berusia antara 24 tahun - 44 tahun sebanyak 55 persen; dengan status perkawinan dengan kawin beranak lebih dari 2 sebesar 45 persen dan berlatar pendidikan perguruan tinggi sebanyak 65 persen; sudah bekerja baik sebagai pegawai swasta maupun negeri sebanyak 80 persen; dengan tingkat penghasilan yang dapat di golongkan sebagai penghasilan tingkat menengah ke atas atau lebih dari Rp. 4.000.000 perbulan adalah sekitar 70 persen; dengan frekuensi kunjungan ke pasar modern/supermarket lebih dari dua kali sebulan adalah 45 persen.Sebagian besar dari mereka menganggap supermarket merupakan bagian dari pemenuhan kebutuhan hidup yaitu sebanyak 70 persen; dimana sebagian besar kebutuhan 
sehari-hari dapat di penuhi di supermarket termasuk tersedianya barang-barang pengganti sebagai alternatif bila barang utama yang di cari tidak ditemui. Sumber informasi paling dominan pada proses keputusan untuk berbelanja ke supermarket di lihat dari usia adalah pada kelompok usia antara 16-24 tahun, sedangkan pada kelompok usia 24-44 tahun keputusan untuk berbelanja ke supermarket lebih bersifat normatif, meskipun kadangkadang informatif dari pihak lain masih di butuhkan. Jika dilihat dari segi pendidikan yang dimiliki seseorang, menunjukkan bahwa semakin tinggi pendidikan yang diperoleh maka semakin tinggi pula status sosial yang dimiliki. Sehingga gaya hidupnya pun akan disesuaikan seiring dengan kemajuan atau perubahan teknologi.

Kualitas serta manfaat yang akan diperoleh dari suatu barang atau merek yang dipilih lebih menjadi perhatian pada kelompok konsumen bergaya hidup serta status sosial yang dipunyai lebih menonjol dibandingkan dengan harga barang yang dibeli. Dengan demikian dapat dikatakan semakin tinggi tingkat pendidikan maka informasi yang diberikan oleh kelompok referensi menjadi kurang berpengaruh. Namun demikian kadang-kadang informasi dari orang lain misalnya dari iklan, brosur, flyer leaflet tentang supermarket masih ada juga pengaruhnya meskipun kecil. Sumber informasi lain dari luar seperti organisasi yang ada kaitan dengan supermarket yaitu lembaga konsumen dan asosiasi pengusaha eceran, meskipun juga merupakan sumber informasi tetapi pengaruhnya tidak sedemikian kuat untuk kelompok tertentu, misalnya kaum intelektual karena mereka lebih banyak memperhatikan kualitas dan manfaat dari sebuah produk sebanding dengan uang yang telah di keluarkan. Hal menarik untuk dikaji berdasarkan data yang di peroleh dari responden yang datang berbelanja ke supermarket adalah mereka yang berasal dari kelompok berpenghasilan diatas Rp. 4.000.000 rupiah per bulan dengan latar belakang pendidikan baik yaitu perguruan tinggi dengan status pekerjaan dan rata-rata penghasilan pada tingkatan cukup tinggi maka terlihat keputusan berbelanja pada kelompok ini lebih di tujukan untuk memperlihatkan status sosial mereka di mata masyarakat. Pengalaman pribadi dapat di jadikan sumber informasi yang kuat karena dapat menentukan dengan pasti apa yang seharusnya dia lakukan pada proses pengambilan keputusan untuk berbelanja di supermarket. Pada beberapa responden, proses pengambilan keputusan untuk berbelanja ke supermarket bersifat normatif. Sementara itu pada beberapa responden diketahui bahwa keputusan yang diambil untuk berbelanja ke supermarket selain bermotif informatif sekaligus normatif. Hal ini dibuktikan mereka berbelanja ke supermarket selain karena mendapatkan informasi dari kelompok referensi tetapi dia juga mendapatkan kebutuhannya sesuai dengan produk serta merek yang di pilih baik manfaat, harga maupun nilainya. Pada proses pemilihan Hypermart Cibubur sebagai tempat yang di pilih untuk mencukupi kebutuhan sehari-hari, ternyata diketahui bahwa selain mereka mendapat informasi dari teman-teman atau anggota keluarga, mereka juga datang karena alasan normatif yaitu karena barang-barang yang dijual mempunyai kemasan, harga, kualitas, manfaat, nilai, aneka ragam, serta fasilitas fisik yang dimiliki dan di tawarkan. Fasilitas fisik antara lain berupa lokasi toko, bentuk bangunan, tata ruang, kelengkapan dan persediaan barang, interior, musik, telepon umum, wc, areal parkir, arena hiburan, kantin, dan sebagainya.kecuali itu bagi sebagian kecil responden.

\section{PENUTUP}

Seiring dengan perubahan lingkungan yang terjadi maka motif para konsumen berbelanja ke supermarket juga berubah. Perubahan tersebut antara lain:

1. Konsumen sekarang dan masa depan, akan peduli terhadap kualitas dan mulai memperhatikan sisi moralitas dan tanggung jawab sosial perusahaan. Dengan kata lain Keputusan Pembelian Konsumen lebih memperhatikan kepada tanggung jawab sosial pemasaran dan dampaknya bagi stake holder secara keseluruhan. Konsumen akan lebih konsen terhadap issue - issue seperti rekayasa produk, penyalahgunaan label dan iklan, serta predatory pricing. Dalam kondisi persaingan lebih ketat dan reputasi perusahaan 
menjadi modal penting, maka setiap kebijakan dan keputusan haruslah didasarkan pada kode etik yang berlaku dan ditetapkan oleh perusahaan maupun asosiasi profesional.

2. Perubahan gaya hidup, dan kesibukan sehari -hari maka terjadi pula perubahan cara dalam berbelanja dari konvensional menuju ke arah online, semakin berkurangnya waktu yang di gunakan untuk berbelanja dari toko ke toko, dan tawar menawar untuk barang-barang keperluan sehari-hari menyebabkan konsumen lebih suka berbelanja secara online

3. Lokasi supermarket yang tidak jauh dari tempat tinggal, fasilitas fisik supermarket yang memadai yaitu lay out, penataan, suasana, jam buka toko yang di sesuaikan dengan waktu luang mereka misalnya mereka dapat berbelanja disana pada hari libur sambil bersantai dengan keluarga.

Semakin sedikitnya waktu luang yang dimiliki oleh konsumen untuk berbelanja ke supermarket maka pemasaran secara online semakin maju dewasa ini, selain itu upermarket yang memiliki nilai lebih misalnya selain menyediakan kebutuhan sehai hari tetapi supermarket juga memiliki fasilitas - fasilitas lain misalnya arena bermain anak, tempat parkir yang luas, tempat bersantai dan tersedia restauran - restauran akan lebih disukai oleh konsumen untuk tidak sekedar berbelanja kebutuhan sehari-hari naun juga bersantai disela - sela kesibukan dan waktu yang sempit Selain itu beberapa strategi umum untuk menyesuaikan dengan perubahan - perubahan ini, antara lain sebagai berikut.

Bagi pembelanjaan normatif adalah sebagai berikut.

1. Harga.

Pada kelompok ini strategi harga yang dilakukan adalah strategi berdasarkan permintaan dimana harga di tentukan menurut kualitas dan citra yang di rasakan konsumen dan bukan biaya yang di keluarkan atau harga yang di tetapkan oleh perusahaan penjual.

2. Produk. Pemilihan barang dan jasa yang di butuhkan oleh konsumen lebih diperhatikan. Strategi ini mungkin akan lebih membantu menarik konsumen baru dengan tipe khusus misalnya barang yang di jual untuk konsumen tertentu.

3. No store selling yaitu penjualan barang dan jasa dengan metode semacam penjualan langsung misalnya vending machine.

4. Online Shopping dilakukan dengan menawarkan produk melalui media online

5. Telemarketing yaitu pemesanan dan berbelanja melalui telepon

6. Specialization yaitu memilih segmen dan produk tertentu yang di jual.

7. Tempat distribusi..

8. Promosi. Penjualan perorangan secara langsung merupakan bentuk strategi paling mendekati kelompok normatif di supermarket tertentu hal yang bisa di lakukan oleh perusahaan-perusahaan untuk mendekati kelompok ini adalah dengan membuat counter terpisah yang berkesan elite dan dengan pramuniaga atau sales promotion girls yang cantik dan menarik serta sangat pandai mempromosikan produk-produk. Dan bagi pembelanja informatif adalah sebagi berikut.Guna menciptakan bentuk informasi yang dapat mempengaruhi proses keputusan untuk melakukan pembelian di supermarket maka di perlukan bentuk komunikasi yang menghubungkan orangluar sebagai orang yang memberikan informasi dengan konsumen dan calon konsumen sebagai penerima informasi. Strategi bauran pemasaran yang di pilih untuk kelompok ini adalah sebagai berikut.

1. Harga. Pada kelompok ini strategi penetapan harga paling tepat adalah dengan strategi harga produk karena harga barang-barang yang di jual di supermarket merupakan barang-barang kebutuhan sehari-hari. Selisih harga yang terjadi antara supermarket yang satu dengan yang lain akan membuat para pembeli mencari supermarket yang menjual dengan harga paling murah. 
2. Produk. Produk-produk yang di jual pada kelompok ini harus produk- produk standar, artinya merupakan produk Yang biasa terdapat dan dijual di lain tempat. Kalaupun terdapat perbedaan biasanya di sebabkan oleh kebersihan, penataan dan kelengkapan barang yang lebih di perhatikan.

3. Tempat. Pada kelompok yang berperilaku informatif, pemilihan tempat adalah selektif artinya penentuan lokasi supermarket merupakan faktor yang mempengaruhi proses keputusan untuk berbelanja di supermarket. Lokasi yang berdekatan dengan tempat tinggal menjadi pilihan utama. Dengan menempatkan supermarket diantara beberapa supermarket akan memberikan pilihan kepada para konsumen untuk datang ke supermarket tertentu.

4. Promosi. Promosi merupakan salah satu bentuk komunikasi yang menjembatani antara produsen dan konsumen atau komunikasi yang menghubungkan antara orang yang memberi informasi dengan orang yang menerima informasi. Untuk kelompok ini beberapa bentuk komunikasi bisa di jalankan. Dan bagi pembelanjaan normatif dan informatif adalah sebagai berikut. Pada kelompok ini, kecuali mereka datang ke supermarket karena informasi yang diterima dari orang lain, mereka juga datang karena barang-barang yang di jual di supermarket termasuk fasilitas fisik yang di miliki toko maka strategi bauran pemasaran untuk kelompok ini adalah sebagai berikut.

1. Harga. pada kelompok ini strategi harga yang di pakai adalah strategi harga permintaan karena mereka tidak peka terhadap harga. Jadi harga di tetapkan menurut permintaan atau harga yang di tetapkan berdasarkan persepsi pembeli.

2. Produk. Produk yang di tawarkan pada kelompok ini bukan hanya produk yang menyajikan bentuk lahiriyah akan tetapi produk yang menjanjikan jasa serta manfaat, misalnya produk yang dijamin dengan pelayanan purna jual dan perawatan.

3. Tempat. Tempat-tempat eksklusif dipilih untuk kelompok ini.

4. Promosi. Promosi dapat di lakukan dengan mengadakan penjualan berhadiah langsung atau dengan memberi kupon yang di berikan untuk pembelian sejumlah tertentu yang di kumpulkan untuk kemudian dapat di pakai guna membeli barang sejumlah harga yang tertera pada kupon tersebut di toko yang sama. Hal ini dapat dilakukan dengan mengirimkan brosur berhadiah terutama untuk barang-barang baru dan mengadakan penjualan berhadiah langsung.

\section{DAFTAR RUJUKAN}

Keller, K. (2013). Analisis Pengaruh Implementasi Manajemen Kualitas. Studi Manajemen Dan Organisasi.

Firmansyah, A. (2019). Perilaku Konsumen (Sikap dan Pemasaran). In Perilaku Konsumen (Sikap dan Pemasaran) Oleh Dr. M.Anang Firmansyah, S.E.,.

Firmansyah, M. A. (2019). Pemasaran Produk dan merek (Planning \& Strategy). Buku Pemasaran Produk Dan Merek.

Hanum, Z., \& Hidayat, S. (2017). Faktor - faktor yang Mempengaruhi Perilaku Konsumen dalam Keputusan Pembelian Sepatu Merek Nike di Kota Medan. Jurnal Bisnis Administrasi.

Khafidin. (2020). Konsep perilaku konsumen beserta implikasinya terhadap keputusan pembelian. Journal Derivatif.

Kotler, A. B. P. (2014). Konsep Kepuasan Philip Kotler. Konsep Kepuasan Philip Kotler.

Kotler, M., \& Kotler, P. (2004). KOTLER. Signs.

Kotler, P. (1991). Kotler on... Management Decision. https://doi.org/10.1108/00251749110004961

Kotler, P. (2017). Philip Kotler: some of my adventures in marketing. Journal of 
Historical Research in Marketing. https://doi.org/10.1108/JHRM-11-2016-0027

Kotler, P., \& Armstrong, G. (2018). Kotler \&amp; Armstrong, Principles of Marketing | Pearson. In Pearson.

Onny Siagian, A. (2020). Keterkaitan Individualitas Manajerial Pemasaran Dalam Menghadapi Revolusi Industri 4.0 Terutama Pada Perusahaan Manufaktur Di Jawa Tengah. Syntax Literate; Jurnal Ilmiah Indonesia, 5(10), 980-994. https://doi.org/http://dx.doi.org/10.36418/syntax-literate.v5i10.1669

Siagian, A. O., Martiwi, R., \& Indra, N. (2020). Kemajuan Pemasaran Produk Dalam Memanfaatkan Media Sosial Di Era Digital. Jurnal Pemasaran Kompetitif. https://doi.org/10.32493/jpkpk.v3i3.4497 